\title{
Effect of OnDuty ${ }^{\mathrm{TM}}$ Herbicide on Weed Populations and Rice Yields in Selected Rice Fields, Melaka, Malaysia
}

(Kesan Herbisid OnDuty ${ }^{\mathrm{TM}}$ terhadap Populasi Rumpai dan Hasil Padi

di Kawasan Penanaman Padi Terpilih, Melaka, Malaysia)

\author{
MARDIANA-JANSAR K.*, BAJRAI F.S.M., MUHAMAD SAFWAN ISHAK \& ISMAIL B.S.
}

\begin{abstract}
The effect of the herbicide OnDuty ${ }^{T M}$ herbicide (imazapic + imazapyr) on the weed population and growth of rice plants was investigated. The study was conducted at Kampung Parit Penghulu Benteng, Sungai Rambai, Melaka for two seasons (season 1 (September-December 2015) and season 2 (February-May 2016)) to identify the weed population and determine the paddy yield components in the paddy field with OnDuty ${ }^{T M}$ application. Six species under four families, namely, Plantaginaceae (Bacopa monnieri), Araceae (Alternanthera sessilis), Cyperaceae (Fimbristylis miliacea, Cyperus iria, Cyperus difformis) and Poaceae (Paspalum distichum, Leptochloa chinensis, Oryza sativa (weedy rice), Echinochloa glabrescens), were found in the rice fields. A. sessilis and $\mathrm{B}$. monnieri are the most abundance weeds found in both seasons. During season one, A. sessilis was the most dominant weed compared with other species. Higher dosage of OnDuty $^{T M}$ up to $300 \mathrm{~g}$ ai/ha OnDuty $^{T M}$ (double recommended dose) did not affect the relative density of weeds and weedy rice can be controlled at half recommended dose. The Clearfield $®$ production system offers control of many weeds especially parasitic weed which missed by other herbicides and adds an effective weed-control tool to rice. In season two, weedy rice was not detected. The yield of rice was significantly higher in plots treated at $300 \mathrm{~g}$ a.i/ha OnDuty ${ }^{T M}$ for both seasons. Thus, OnDuty ${ }^{T M}$ can effectively control weedy rice at half recommended dose and increase rice yield at double recommended dose.
\end{abstract}

Keywords: Herbicide OnDuty ${ }^{T M}$; rice yield; weed population

ABSTRAK

Kesan herbisid OnDuty ${ }^{T M}$ terhadap populasi dan pertumbuhan tanaman padi telah dikenal pasti. Kajian dijalankan di Kampung Parit Penghulu Benteng, Sungai Rambai, Melaka untuk dua musim iaitu musim pertama (September-Disember 2015) dan musim kedua (Februari-Mei 2016) untuk mengenal pasti populasi rumpai dan menentukan komponen hasil padi di kawasan sawah padi dengan penggunaan herbisid OnDuty ${ }^{T M}$. Terdapat enam spesies di bawah empat famili telah ditemui di sawah padi yang dikaji iaitu Plantaginaceae (Bacopa monnieri), Araceae (Alternanthera sessilis), Cyperaceae (Fimbristylis miliacea, Cyperus iria, Cyperus difformis) dan Poaceae (Paspalum distichum, Leptochloa chinensis, Oryza sativa (padi angin), Echinochloa glabrescens). Spesies rumpai A. sessilis dan B. monnieri adalah rumpai yang paling banyak terdapat di kedua-dua musim yang ditetapkan. Pada musim pertama, A. sessilis merupakan rumpai yang paling dominan berbanding spesies lain. Peningkatan dos kepekatan herbisid OnDuty ${ }^{T M}$ sehingga 300 g ai/ha OnDuty ${ }^{T M}$ (dua kali dos yang disyorkan) tidak menjejaskan ketumpatan relatif rumpai dan padi angin boleh dikawal pada separuh dos yang disyorkan. Sistem pengeluaran Clearfield® menawarkan kawalan pelbagi jenis rumpai terutamanya rumpai parasit yang tidak dapat dikawal oleh herbisid yang lain dan menjadi satu alat kawalan yang berkesan dalam penanaman padi. Padi angin tidak dapat dikesan pada musim kedua. Penghasilan padi jauh lebih tinggi pada plot yang dirawat dengan kepekatan $300 \mathrm{~g}$ a.i/ha OnDuty ${ }^{T M}$ untuk kedua-dua musim. Ini menunjukkan bahawa herbisid OnDuty ${ }^{T M}$ amat berkesan untuk mengawal padi pada separuh kepekatan dos yang disyorkan dan meningkatkan penghasilan padi jika menggunakan dua kali kepekatan dos yang disyorkan.

Kata kunci: Hasil padi; herbisid OnDuty ${ }^{T M}$; populasi rumpai

\section{INTRODUCTION}

Malaysia produces $70 \%$ of its rice consumption and import $30 \%$ of the production to other countries which influence the importance to increase rice production. Rice cultivation activities on a large or small scale are also threatened with the existence of weed populations. Weed infestation known as one of the major constraints of the plantation industry in Malaysia and compete with the cultivated crops such as rice. According to Moody (1989), there are more than 1,800 plant species recorded as rice weeds in southern Asia and Southeast Asia. The direct seeding of rice cultivation which is preferred to most farmers led to the diversification of weed species found in rice fields (Pane et al. 2000; Rao et al. 2007; Skinner \& Taylor 2002; Smith \& Dilday 
2003). Weed threats in rice cultivation are very serious in Malaysia, because it could cause quality and quantity deterioration of rice yields. The study conducted by Azmi (2002) and Noda (1977) showed that the losses caused by weeds for rice cultivation areas ranged from 16-68\% and could reach up to $96 \%$ depending on the cultivation technique used, either using direct seeding methods or transplanting techniques. Various countries including Malaysia, Thailand and Indonesia have recorded losses from weed competition in their paddy cultivation areas of $40-60 \%, 25-50 \%$ and $26-43 \%$, respectively (Saharan 1977; Sundaru 1979).

The most abundance tapered weed species in rice cultivation in Malaysia are Echinochloa crus-galli, Leptochloa chinensis, Echinochloa colona, Oryza sativa L. (rice paddy) and Ischaemum rugosum (Hakim et al. 2013). Previous studies conducted by Begum et al. (2008) reported that $O$. sativa L. is the most widely found weed species in the Muda area of Kedah, Malaysia followed by E. crus-galli, L. chinensis, Ludwigia hyssopifolia and Fimbristylis miliacea. A similar pattern of weed control can be seen in a comprehensive study conducted by Azmi and Baki (2007) from 2002 to 2005. Various strategies of weed management have been practiced to limit the weed population. The use of herbicides, insecticides and fungicide is one of the most popular ways to protect paddy plants from algae, weeds, insects and diseases. Malaysian Government has spent million dollars to develop agricultural sector and introduced a variety of modern agricultural inputs such as pesticides and fertilizers (Fuad et al. 2012). According to Seng et al. (2018), reliability towards herbicides to eliminate weeds such as Eleusine indica has led to development of several herbicides such as paraquat, glufosinate and gyphosate. In 2010, farmers in Malaysia were introduced to the Clearfield ${ }^{\circledR}$ Production System (CPS) which is known as the most successful approach to control paddy (Azmi et al. 2012). The current prominent use of imazapic and imazapyr as active ingredients in the OnDuty ${ }^{\mathrm{TM}}$ herbicide formulation successfully helped to increase the yield of paddy in Malaysia (3.5-7 metric tonnes per hectare) in the area where CPS was practiced (Bajrai et al. 2017; Sudianto et al. 2013). In accordance with standardized procedures at CPS, farmers are encouraged to use at a rate of $150 \mathrm{~g}$ ai $\mathrm{ha}^{-1}$ herbicide for better performance in controlling weedy rice.

The dose-response model was introduced by Streibig (1980) in 1985, Cousens (1985) developed a rectangular hyperbolic model that explains the linkage between crop yield losses to weed density. Few studies have been carried out to examine the relationship between herbicide performance to the density of selected weed species against yield performance (Kim et al. 2002; Moon et al. 2014, 2010; Oveisi et al. 2013). The developed models can help in determining the appropriate dose to control selected weed species in winter wheat, rice and corn cultivation. Recent studies have also been conducted to identify the effect of herbicide doses and weed density on yield performance for rice through competition between weeds and weedy rice (Bajrai et al. 2015; Chauhan et al. 2014; Duong et al. 2007). However, the research was not developed to the next stage to determine the long-term impact of weedy rice density on paddy yield performance through the modeling method. An ideal model for determining the ideal dose of herbicides to control weeds in rice cultivation may help in improving rice yield performance. Therefore, this research was conducted to study the relationship between density of weeds commonly found in paddy cultivation; namely Oryza sativa L. (weedy rice), Alternanthera sessilis and Fimbristylis miliacea against herbicide dosage and then incorporated in rectangular hyperbolic model. The objectives of this study were to identify the weed population in the rice field with herbicide treatment in different concentrations for two planting seasons; determining the number of rice yield components according to different herbicide rates for two planting seasons and applying a mathematical model in studying relationship of the population for selected weed towards herbicide dosage for two planting seasons.

\section{EXPERIMENTAL PLOT}

The study was conducted at Kg Parit Penghulu Benteng, Sg Rambai, Melaka. All the weed samples used in this study were the samples obtained in the experimental plot, in the rice field area of $\mathrm{Kg}$ Parit Penghulu Benteng, Sg Rambai, Melaka ( $2^{\circ} 07^{\prime} 48.1^{\prime \prime} U 102^{\circ} 30$ '32.6'T). Different rates of OnDuty ${ }^{\mathrm{TM}}$ herbicide, ie 0 (control), 75, 150 and $300 \mathrm{~g}$ a.i/ha were sprayed on four rice fields, which is about one hectare and applied on the third day after seeding. During the field study period, the average daily temperature and the total rainfall amount were $27.7^{\circ} \mathrm{C}$ and $30.2 \mathrm{~mm}$, respectively, in the first season (September-December 2015) and $28.9^{\circ} \mathrm{C}$ and $18.9 \mathrm{~mm}$ in the second season (February-May 2016). The experimental design that has been used is a complete randomized design with three replications. These plots were randomly selected with each plot size of $4 \times 4 \mathrm{~m}$.

\section{WEED POPULATION}

In each experimental plot, a $1 \mathrm{~m}^{2}$ census quadrat survey was randomized to determine the weed population (Kim \& Keith 1983). In this method, all individuals in the quadrat are calculated. Three quadrat sampling were taken for each experimental plot. Determination of this weed population is based on analysis of weed vegetation. Density (d), absolute density, relative density $\left(\mathrm{R}_{\mathrm{d}}\right)$, relative frequency $\left(\mathrm{R}_{\mathrm{f}}\right)$, importance value $\left(\mathrm{IV}_{\mathrm{i}}\right)$ and summed dominance ratio (SDR) of each weed species were calculated based on the following formula (Brower 1984):

Density is the individual value per unit area, $d=n_{i} / \mathrm{A}$

$n_{i}=$ total number of individuals based on species $i$

$\mathrm{A}=$ observational plot area 
Relative density, $\left(\mathrm{R}_{d}\right)$ refers to the number of individual species density calculated based on the percentage of total individual density of all species

$$
\begin{aligned}
\mathrm{R}_{d}= & \left(\mathrm{d}_{i} / \Sigma \mathrm{d}\right) \times 100 \% \\
\mathrm{~d}_{i}= & \text { number of individuals per species in one } \\
& \text { observational plot area } \\
\Sigma \mathrm{d}= & \text { total number of species in whole observational } \\
& \text { plot area }
\end{aligned}
$$

Relative frequency, $\left(\mathrm{R}_{f}\right)$ is the number of species frequencies calculated based on the percentage of total number of individuals for all species

$$
\begin{aligned}
& \mathrm{R}_{f}=\mathrm{f}_{i} / \Sigma \mathrm{f} \times 100 \% \\
& \mathrm{f}_{i}=\text { number of frequencies of species } i, \\
& \Sigma \mathrm{f}=\text { total number of frequencies of all species }
\end{aligned}
$$

The importance value $\left(\mathrm{IV}_{i}\right)$ is used to calculate the importance index for each species and family

$$
\mathrm{IV}_{i}=\left(\mathrm{R}_{f}+\mathrm{R}_{d}\right)
$$

Summed Dominance Ratio, (SDR) is aimed at representing the dominant relation of a species with another species in a community, i.e. after the treatment of herbicides at different concentrations. Species with an SDR value greater than $5 \%$ are considered to be significant or dominant in a particular region (Sastroutomo \& Pandegirot 1988).

$$
\begin{aligned}
& \mathrm{SDR}=\mathrm{IV}_{i} / 2 \\
& \mathrm{IV}_{i}=\text { importance value of species } i
\end{aligned}
$$

\section{WEED RECOGNITION}

The identification is based on the morphological characteristics to denote all genus and species of weeds (Naidu 2012). The collected weed samples were dried at $70^{\circ} \mathrm{C}$ for $72 \mathrm{~h}$ until the specimen was completely dry. The dry biomass was weighed and recorded.

\section{RICE HARVESTING}

The sampling was carried out during the harvesting period (110 days) to obtain rice yield component data. A square meter of $1 \mathrm{~m} \times 1 \mathrm{~m}$ was randomly used in rice plot. Data on rice yields were obtained using the formula from Basuchaudhuri (2014) and Moon et al. (2014) which include parameters such as the length and number of the stalks of each rice bunch, number of grains of each stalk, the percentage of empty grains of each rice stalk and the weight of 1000 rice grains. The yield (Y) can be estimated by combining the main yield components and the equation as follow:

$$
\begin{aligned}
Y= & \left(\frac{\text { number of stalks }}{\text { observation area }}\right) \times(\text { number of grains in each stalk }) \\
& \times(\% \text { ripe grains }) \times(\text { weight of } 1000 \text { rice grains })
\end{aligned}
$$

\section{STATISTICAL ANALYSIS}

The relationship between rice yield component and weed density based on different dosage of herbicides was analysed by using one-way analysis of variance (ANOVA) with Tukey HSD test with significant values of $p$ $\leq 0.05$. Multivariate analysis using principal component analysis (PCA) was then carried out to collect the physical parameters (spraying and weed density) with the same characteristics (calculated by the quantitative descriptive analysis). The purpose of the PCA is to find some directly related parameters to the properties of the two axes, so that predictive models based on this parameter are feasible (Xia et al. 2009). Statistical calculations were performed using XLSTAT (vs. 2011/02/04, Addinsoft, Andernach, Germany). In order to detect the interaction and to measure the effect of spray variation and composition weed density on the sensory characteristics, the ANOVA model was used and compared with the XLSTAT software.

\section{RESULTS AND DISCUSSION}

\section{WEED COMPOSITION}

The composition of the weed found in experimental plots in seasons one and two are as Table 1.A total of six species of weeds belong to four families comprising broad leaf weeds, tapered weeds, sedges and aquatic weeds were identified, namely, Plantaginaceae (Bacopa monnieri), Araceae (Alternanthera sessilis), Cyperaceae (Fimbristylis miliacea, Cyperus iria and Cyperus difformis) and Poaceae (Paspalum distichum, Leptochloa chinensis, Oryza sativa and Echinochloa glabrescens). According to Mishra et al. (2015), A. sessilis, C. iria and F. miliacea are among the species of weeds that are usually found in wetland areas.

Based on Table 1, uniformity of weed species in study plots indicates that there is a shift from a weed species to another weed species. According to Altieri and Liebman (1988), weed species that do not have high competitive power will be replaced with weed species with high competitive power. Table 2 records the dry weight value of each weed species in season one and two. The results showed that only two species had significant differences in variation of herbicide spray doses, namely F. miliacea and P. distichum. For season two, B. monnieri and A. sessilis species showed significant differences in different doses of herbicide application.

The minimum dry weight found at sprays plots of $300 \mathrm{~g}$ ai/ha was $33.80 \mathrm{~g} \mathrm{~m}^{-2}$ while maximum dry weight recorded in control plot was $94.84 \mathrm{~g} \mathrm{~m}^{-2}$. A similar pattern was observed in the season two where the minimum dry weight found at plots treated with $300 \mathrm{~g}$ ai/ha rate was $13.21 \mathrm{~g} \mathrm{~m}^{-2}$ while the maximum dry weight recorded in 
TABLE 1. Composition of dominant weed flora and family name, type and relative density (RD) in experimental plot according to different herbicide rates in Season 1 (September 2015 - December 2015) and Season 2 (February 2016 - May 2016)

\begin{tabular}{|c|c|c|c|c|c|c|}
\hline \multirow{2}{*}{ Species } & \multirow{2}{*}{ Family } & \multirow{2}{*}{ Type } & \multicolumn{4}{|c|}{$\mathrm{RD}(\%)$ for different rates of herbicides ( $\mathrm{g}$ ai/ha) } \\
\hline & & & 0 & 75 & 150 & 300 \\
\hline \multicolumn{7}{|l|}{ Season one } \\
\hline Bacopa monnieri & Plantaginaceae & Broad Leaf & $22.70^{\mathrm{a}}$ & $32.96^{\mathrm{a}}$ & $3.92^{\mathrm{a}}$ & $0.00^{\mathrm{a}}$ \\
\hline Alternanthera sessilis & Araceae & Broad Leaf & $46.15^{\mathrm{a}}$ & $22.72^{\mathrm{a}}$ & $11.85^{\mathrm{a}}$ & $48.23^{\mathrm{a}}$ \\
\hline Fimbristylis miliacea & Cyperaceae & Sedges & $15.23^{\mathrm{ab}}$ & $39.37 \mathrm{ab}$ & $70.62^{\text {a }}$ & $0.00^{\mathrm{b}}$ \\
\hline Paspalum distichum & Poaceae & Tapered weed & $15.21^{\mathrm{a}}$ & $4.95^{\mathrm{a}}$ & $0.00^{\mathrm{a}}$ & $0.00^{\mathrm{a}}$ \\
\hline Oryza sativa & Poaceae & Tapered weed & $6.82^{\mathrm{a}}$ & $0.00^{\mathrm{a}}$ & $0.00^{\mathrm{a}}$ & $0.00^{\mathrm{a}}$ \\
\hline Cyperus iria & Cyperaceae & Sedges & $0.00^{\mathrm{a}}$ & $0.00^{\mathrm{a}}$ & $13.61^{\mathrm{a}}$ & $53.70^{\mathrm{a}}$ \\
\hline \multicolumn{7}{|l|}{ Season two } \\
\hline Bacopa monnieri & Plantaginaceae & Broad Leaf & $34.52^{\mathrm{a}}$ & $45.93^{\mathrm{a}}$ & $49.76^{\mathrm{a}}$ & $47.09^{\mathrm{a}}$ \\
\hline Alternanthera sessilis & Araceae & Broad Leaf & $29.68^{\text {a }}$ & $38.14^{\mathrm{a}}$ & $45.50^{\mathrm{a}}$ & $38.58^{\text {a }}$ \\
\hline Leptochloa chinensis & Poaceae & Tapered weed & $20.07^{\text {a }}$ & $12.33^{\mathrm{ab}}$ & $4.74^{\mathrm{ab}}$ & $0.00^{\mathrm{b}}$ \\
\hline Cyperus difformis & Cyperaceae & Sedges & $1.60^{\mathrm{a}}$ & $8.33^{\mathrm{a}}$ & $0.00^{\mathrm{a}}$ & $14.33^{\mathrm{a}}$ \\
\hline Echinochloa glabrescens & Poaceae & Tapered weed & $15.00^{\mathrm{a}}$ & $0.00^{\mathrm{a}}$ & $0.00^{\mathrm{a}}$ & $0.00^{\mathrm{a}}$ \\
\hline
\end{tabular}

aPercentage of relative density mean value for different letters between rows shows a significant difference $(\mathrm{p}<0.05)$ after analyzed by the Tukey HSD Test

TABLE 2. Weed dry weight (WDW) $\left(\mathrm{g} / \mathrm{m}^{2}\right)$ on the effects of herbicide application at different concentrations in season 1 (September 2015 - December 2015) and season two (February 2016 - May 2016)

\begin{tabular}{lcccc}
\hline \multirow{2}{*}{ Species } & \multicolumn{4}{c}{ WDW $\left(\mathrm{g} \mathrm{m}^{-2}\right)$ for for different rates of herbicides (g ai/ha) } \\
\cline { 2 - 5 } & 0 & 75 & 150 & 300 \\
\hline Season one & & & \\
Bacopa monnieri & $9.00^{\mathrm{a}}$ & $15.88^{\mathrm{a}}$ & $1.93^{\mathrm{a}}$ & $0.00^{\mathrm{a}}$ \\
Alternanthera sessilis & $18.91^{\mathrm{a}}$ & $9.56^{\mathrm{a}}$ & $6.47^{\mathrm{a}}$ & $5.14^{\mathrm{a}}$ \\
Fimbristylis miliacea & $16.98^{\mathrm{bc}}$ & $45.66^{\mathrm{a}}$ & $29.50^{\mathrm{ab}}$ & $0.00^{\mathrm{c}}$ \\
Paspalum distichum & $43.14^{\mathrm{a}}$ & $15.83^{\mathrm{b}}$ & $0.00^{\mathrm{b}}$ & $0.00^{\mathrm{b}}$ \\
Oryza sativa & $6.82^{\mathrm{a}}$ & $0.00^{\mathrm{a}}$ & $0.00^{\mathrm{a}}$ & $0.00^{\mathrm{a}}$ \\
Cyperus iria & $0.00^{\mathrm{a}}$ & $0.00^{\mathrm{a}}$ & $28.66^{\mathrm{a}}$ & $28.66^{\mathrm{a}}$ \\
Season two & & & \\
Bacopa monnieri & & & \\
Alternanthera sessilis & $6.96^{\mathrm{b}}$ & $35.98^{\mathrm{a}}$ & $21.78^{\mathrm{ab}}$ & $5.20^{\mathrm{b}}$ \\
Leptochloa chinensis & $10.12^{\mathrm{b}}$ & $26.56^{\mathrm{a}}$ & $15.20^{\mathrm{b}}$ & $5.09^{\mathrm{b}}$ \\
Cyperus difformis & $9.19^{\mathrm{a}}$ & $7.98^{\mathrm{a}}$ & $2.52^{\mathrm{a}}$ & $0.00^{\mathrm{a}}$ \\
Echinochloa glabrescens & $6.72^{\mathrm{a}}$ & $12.86^{\mathrm{a}}$ & $0.00^{\mathrm{a}}$ & $2.91^{\mathrm{a}}$ \\
Bacopa monnieri & $20.72^{\mathrm{a}}$ & $0.00^{\mathrm{a}}$ & $0.00^{\mathrm{a}}$ & $0.00^{\mathrm{a}}$ \\
\hline
\end{tabular}

${ }^{a}$ Average dry weight for different letters between rows shows a significant difference $(\mathrm{p}<0.05)$ after analysed by the Tukey HSD Test

the plots where that herbicide sprayed at a rate of $75 \mathrm{~g}$ ai/ ha was $83.37 \mathrm{~g} \mathrm{~m}^{-2}$.

Plant weight calculation is a suitable step to evaluate competitive of weed, as it reflects on how much disruption has been received by every plant species (De Vida et al. 2006). The higher the plant density, the higher the dry weight of the plant, which ultimately leads to a higher weed suppression (Weiner et al. 2001). The weed dry weights in season one are much higher than the second season due to the difference in dominant weed sizes. More appearance of sedges and tapered weeds contributed to the increase in the dry weights of weeds in season one. It is supported by the findings of Tanaka (1963), where sedges and tapered weeds can contribute up to $90 \%$ of the total weight of weeds in rice fields ecosystems.

Based on the SDR value shown in Table 3, the most dominant species in season one varied with the herbicide rate. A. sessilis was the most dominant in the control plots whereas $C$. iria was the most dominant species in the highest herbicide dosage application. F. miliaceae was the dominant species in rice field sprayed herbicides at doses of 75 and $150 \mathrm{~g}$ ai/ha. Even though the weedy rice was found in control plots, the low SDR values indicate that the weedy rice was not the dominant species in all four plots in this study. In the season two, B. monnieri was found as the dominant weed as it recorded the highest 
SDR value for four rice fields plots. This is also confirmed by statistical analysis, which showed that there was no significant difference in the value of SDR in B. monnieri for all doses of herbicide.

Based on a study conducted by Ho and Zuki (1988), direct rice seeding paddy modified the presence of weed groups from broad leave weeds and sedges to tapered weeds from Poaceae family. In this study, both planting seasons were conducted using direct seeding method because it is easier and time saving to farmers. Generally, the species of Poaceae and Cyperaceae are more abundant than any other families, due to wet soil or saturated conditions in rice field ecosystems. This condition supports the growth of tapered weeds and sedges (De Datta 1981).

Soil moisture after cultivation is the major factor affecting the composition of weed flora and domination patterns of major weed species in the community (Moody \& Drost 1983). According to Bhager et al. (1999), Echinochloa and Leptochloa weeds species are particularly favorable for wet soil condition. In this study, season two was warmer and caused lack of water resources in rice fields, therefore tapered weeds dominated the average WDW in the control plots. The results of this study agreed with Bhager et al. (1999), that there are two species of Echinochloa and Leptochloa groups found, that are E. glabrescens and L. chinensis. According to Holst et al. (2007), the study on weed population should use the appropriate model and approach so that the results of the study are accurate. Therefore, this study was further extended by comparing the value of weed dry weight (Tables 2) obtained with the average yield of rice $(\mathrm{t} / \mathrm{ha})$ for each season (Table 4$)$.

\section{RICE YIELD COMPONENTS}

To calculate the yield of rice, parameters such as panicle length and number of panicle of each rice clump, the number of grains and the percentages of empty grain for each panicle, and the weight of 1000 grains were recorded. Table 4 shows the rice yield components in season one and two.

Table 4 shows the longest length of panicle for each rice clump in season one is applied at the highest herbicide concentrations, which is $300 \mathrm{~g}$ ai/ha followed by $150 \mathrm{~g}$ ai/ ha with $18.85 \mathrm{~cm}$ and $17.70 \mathrm{~cm}$ length, respectively. The panicle length in the season two appeared to decrease in all doses of herbicide, accordingly and there was no significant difference between the concentration of control and $75 \mathrm{~g}$ ai/ ha and the concentration of 75 and $150 \mathrm{~g}$ ai/ha. The highest panicle length recorded for the second season was 18.17 $\mathrm{cm}$ compared to $18.85 \mathrm{~cm}$ for the first season. According to Faruk et al. (2013), the intensification in herbicides rate affected the length of the panicle, and this study supported their findings. Generally, the number of panicles per plant showed a significant difference between different rates of herbicide and control plots. A study conducted in Bangladesh showed that the higher application rate of herbicide, the higher the average number of panicles (Hossain \& Rahman 2013). Differed from this study, a significant differences was shown between the control plots and the plots that have been sprayed with several types of herbicides (Hossain \& Rahman 2013).

The number of grains per panicle in season one and two referred at different rates of herbicide was not significantly different (Table 3). The number of grains per panicle was increasing with the increase in dose of herbicide. However, there was no significant difference between 0,75 and 150 $\mathrm{g}$ ai/ha rates and between 75, 150 and $300 \mathrm{~g}$ ai/ha rates for both seasons. A significant difference was found only between 0 and $300 \mathrm{~g}$ ai/ha rates. According to Juraimi et al. (2009), the extra number of panicles can increase the grain yield per plant and this study verified the similar results. The results also showed that the number of grains per

TABLE 3. Value of summed dominance ratio (SDR) for weeds based on different rates of imazapic and imazapyr in season one and season two

\begin{tabular}{lcccc}
\hline \multirow{2}{*}{ Species } & \multicolumn{4}{c}{ Herbicide rates (g ai/ha) } \\
\cline { 2 - 5 } & 0 & 75 & 150 & 300 \\
\hline Season one & & & \\
Bacopa monnieri & $23.02^{\mathrm{a}}$ & $30.37^{\mathrm{a}}$ & $10.29^{\mathrm{ab}}$ & $0.00^{\mathrm{b}}$ \\
Alternanthera sessilis & $34.74^{\mathrm{a}}$ & $19.69^{\mathrm{a}}$ & $19.82^{\mathrm{a}}$ & $39.81^{\mathrm{a}}$ \\
Fimbristylis miliacea & $19.28^{\mathrm{ab}}$ & $33.58^{\mathrm{a}}$ & $49.20^{\mathrm{a}}$ & $0.00^{\mathrm{b}}$ \\
Paspalum distichum & $19.28^{\mathrm{a}}$ & $16.36^{\mathrm{a}}$ & $0.00^{\mathrm{b}}$ & $0.00^{\mathrm{b}}$ \\
Oryza sativa & $3.68^{\mathrm{a}}$ & $0.00^{\mathrm{a}}$ & $0.00^{\mathrm{a}}$ & $0.00^{\mathrm{a}}$ \\
Cyperus iria $\mathrm{L}$ & $0.00^{\mathrm{b}}$ & $0.00^{\mathrm{b}}$ & $20.70^{\mathrm{ab}}$ & $60.19^{\mathrm{a}}$ \\
Season two & & & \\
Bacopa monnieri & & $44.32^{\mathrm{a}}$ & $42.99^{\mathrm{a}}$ \\
Alternanthera sessilis & $30.32^{\mathrm{a}}$ & $36.86^{\mathrm{a}}$ & $42.19^{\mathrm{a}}$ & $38.73^{\mathrm{ab}}$ \\
Leptochloa chinensis & $27.89^{\mathrm{b}}$ & $32.96^{\mathrm{ab}}$ & $13.48^{\mathrm{ab}}$ & $0.00^{\mathrm{b}}$ \\
Cyperus difformis & $23.09^{\mathrm{a}}$ & $20.05^{\mathrm{a}}$ & $0.00^{\mathrm{a}}$ & $18.28^{\mathrm{a}}$ \\
Echinochloa glabrescens & $4.13^{\mathrm{a}}$ & $5.30^{\mathrm{a}}$ & $0.00^{\mathrm{a}}$ & $0.00^{\mathrm{a}}$ \\
\hline
\end{tabular}

${ }^{a}$ Average SDR for different letters between rows shows a significant difference $(\mathrm{p}<0.05)$ after analysed by the Tukey HSD Test 
TABLE 4. Rice yield component based on different concentration of herbicides in season one

\begin{tabular}{|c|c|c|c|c|}
\hline \multirow{2}{*}{ Species } & \multicolumn{4}{|c|}{ Herbicide rates (g ai/ha) } \\
\hline & 0 & 75 & 150 & 300 \\
\hline \multicolumn{5}{|l|}{ Season one } \\
\hline Panicle length per plant $(\mathrm{cm})$ & $16.49^{c}$ & $16.73^{c}$ & $17.64^{\mathrm{b}}$ & $18.58^{a}$ \\
\hline Panicles per plant & $10.83^{\mathrm{b}}$ & $12.33^{\mathrm{a}}$ & $12.58^{\mathrm{a}}$ & $12.42^{\mathrm{a}}$ \\
\hline Grains per panicle & $88.42^{\mathrm{b}}$ & $93.58^{b}$ & $94.92^{b}$ & $106.42^{\mathrm{a}}$ \\
\hline Empty grains per panicle & $23.33^{\mathrm{a}}$ & $21.83^{\mathrm{a}}$ & $20.33^{\mathrm{a}}$ & $17.33^{\mathrm{a}}$ \\
\hline Grains yield per panicle $(\mathrm{g})$ & $111.75^{\mathrm{b}}$ & $115.42^{\mathrm{ab}}$ & $117.83^{\mathrm{ab}}$ & $123.75^{\mathrm{a}}$ \\
\hline Percentage of empty grain per panicle & $24.11^{\mathrm{a}}$ & $19.47^{\mathrm{ab}}$ & $17.83^{\mathrm{bc}}$ & $14.19^{c}$ \\
\hline Weight of 1000 grains & $25.18^{\mathrm{b}}$ & $26.01^{b}$ & $31.66^{\mathrm{a}}$ & $33.42^{\mathrm{a}}$ \\
\hline Yield (t/ha) & 2.47 & $3.03^{\mathrm{c}}$ & $3.88^{\mathrm{b}}$ & $4.22^{\mathrm{a}}$ \\
\hline \multicolumn{5}{|l|}{ Season two } \\
\hline Panicle length per plant $(\mathrm{cm})$ & $16.14^{\mathrm{c}}$ & $16.42^{\mathrm{bc}}$ & $16.95^{\mathrm{b}}$ & $18.17^{\mathrm{a}}$ \\
\hline Panicles per plant & $10.08^{b}$ & $11.00^{\mathrm{ab}}$ & $10.92^{\mathrm{ab}}$ & $11.83^{\mathrm{a}}$ \\
\hline Grains per panicle & $84.83^{\mathrm{b}}$ & $90.25^{\mathrm{b}}$ & $90.25^{\mathrm{b}}$ & $102.58^{\mathrm{a}}$ \\
\hline Empty grains per panicle & $23.67^{\mathrm{a}}$ & $23.75^{\mathrm{a}}$ & $22.75^{\mathrm{a}}$ & $18.00^{\mathrm{a}}$ \\
\hline Grains yield per panicle $(\mathrm{g})$ & $108.50^{\mathrm{b}}$ & $114.00^{\mathrm{ab}}$ & $113.00^{\mathrm{ab}}$ & $120.58^{a}$ \\
\hline Percentage of empty grain per panicle & $22.14 \mathrm{a}^{\mathrm{a}}$ & $21.32^{\mathrm{a}}$ & $20.24^{\mathrm{ab}}$ & $15.08^{\mathrm{b}}$ \\
\hline Weight of 1000 grains & $24.75^{\mathrm{b}}$ & $24.90^{\mathrm{b}}$ & $30.87^{\mathrm{a}}$ & $31.34^{\mathrm{a}}$ \\
\hline Yield (t/ha) & $2.23^{\mathrm{c}}$ & $2.57^{\mathrm{c}}$ & $3.13^{\mathrm{b}}$ & $3.68^{\mathrm{a}}$ \\
\hline
\end{tabular}

aAverage SDR for different letters between rows shows a significant difference $(\mathrm{p}<0.05)$ after analysed by the Tukey HSD Test

panicle was lower in the second season due to the shortage of sufficient water resources to maintain a minimum water depth and agreed with the findings of Jahan (2004) who found that the number of cereal per panicle in appropriate water level has the highest value, compared to the saturated soil condition.

The weight of 1,000 rice grain had significant difference between applied herbicide rates as reported by other researcher (Ahmed \& Chauhan 2014; Jahan 2004). Rice yields recorded an increase in the experimental plots from herbicide rate of $0 \mathrm{~g}$ ai/ha (control) to $300 \mathrm{~g}$ ai/ha. The highest weight for rice yield per hectare for season one is at the concentration of herbicide $300 \mathrm{~g}$ ai/ha (4.22 $\mathrm{t} / \mathrm{ha}$ ), while control condition recorded the lowest yield (2.47 t/ha). Similar results found in the season two with a significant difference to all rates. Controlling weeds through the same methods will increase the yield of rice (Ahmed \& Chauhan 2014). This study showed that the $300 \mathrm{~g}$ ai/ha herbicide treated plots had the least number of weed species compared to other concentrations for both seasons. In addition, the treated plots did not have $F$. miliacea (Cyperaceae family) that give adverse effect on the growth and yield of rice (Begum et al. 2009; Watanabe 1997).

\section{MULTIVARIATE ANALYSIS}

Score plot pairs provided an overview of the various separation patterns between the most significant components. High percentage of principle component (PC) of the season one and two showed that almost all the variances in the original data set can be explained through the first and second coordinates (Bouterfas et al.
2014). Based on the score plot, PC1 and PC2 in season one are $51.3 \%$ and $20 \%$, respectively, and PC1 and PC2 in season two are $51.8 \%$ and $24.4 \%$, respectively (Table 5). Subsequently, a scree plot was plotted to show the number of rejected components from the original data. According to Cattell (2012), this scree plot is curved at the beginning and thereby establishes a linear relationship where the curve becomes a straight line and is identified as the maximum number of disputed components. Based on both score and scree plot, five PCs are identified.

Figure 1(A) (season one) and 1(B) (season two) show the data projection of two main components of the PCs which illustrate the rates of herbicide affecting the selected weed density. Since the position of legends in score plot located close to each other, means that the herbicide dose has almost identical or homogenous behavior in determining the relative density of weed populations (Krzyśko-Lupicka et al. 2016). In season one, the ellipse position appeared to be close to each other, while in the season two the ellipse position for the control dose ( $0 \mathrm{~g}$ ai/ha) located far from the three other rates. This illustration shows the relative density of weeds populations increased unexpectedly when no herbicide was applied in season two.

The principal component analysis (PCA) was carried out for ten variables to produce a model that describe positive or negative relationships between herbicide rate and relative density of weeds for both seasons. There are two main components (PCs) that can be varied from ten variables, after varimax rotation is performed based on eigenvalues $>1$ (Kim \& Mueller 1978). The value of each PCs is shown in Table 5. Both major PCs contributed $71.30 \%$ of the total variance (PC1 42.30\%; 
TABLE 5. Varimax variance based on eigenvalue $>1$ for two principle component axes

\begin{tabular}{lcccc}
\hline \multirow{2}{*}{ Species } & \multicolumn{2}{c}{ Season 1 } & \multicolumn{2}{c}{ Season 2 } \\
\cline { 2 - 5 } & PC1 & PC2 & PC1 & PC2 \\
\hline Eigenvalue & 2.72 & 1.28 & 2.31 & 1.51 \\
Variability (\%) & 51.30 & 20.00 & 51.80 & 24.40 \\
Cumulative \% & 51.30 & 71.30 & 51.80 & 76.20 \\
Bacopa monnieri & 0.86 & 0.20 & 0.91 & 0.09 \\
Alternanthera sessilis & 0.48 & 0.54 & 0.95 & 0.14 \\
Fimbristylis miliacea & 0.93 & -0.18 & - & - \\
Paspalum distichum & 0.21 & 0.77 & - & - \\
Weedy rice & -0.07 & 0.74 & - & - \\
Cyperus iria & -0.69 & -0.37 & - & - \\
Leptochloa chinensis & - & - & 0.59 & -0.16 \\
Cyperus difformis & - & - & 0.34 & 0.86 \\
Echinochloa glabrescens & - & - & -0.30 & 0.87 \\
\hline
\end{tabular}

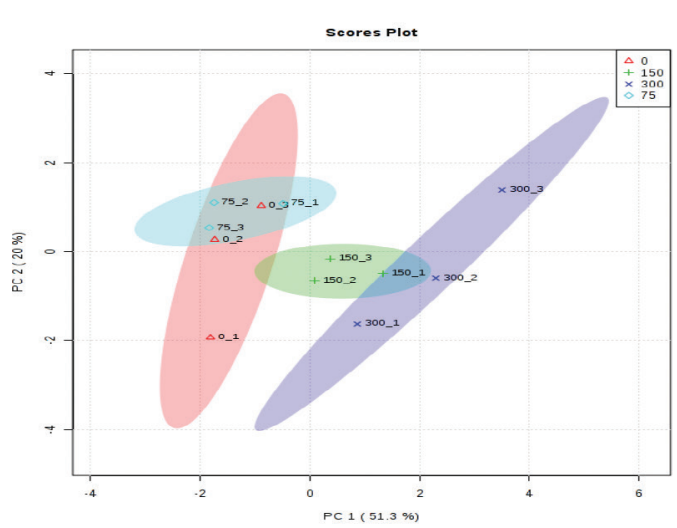

(A)

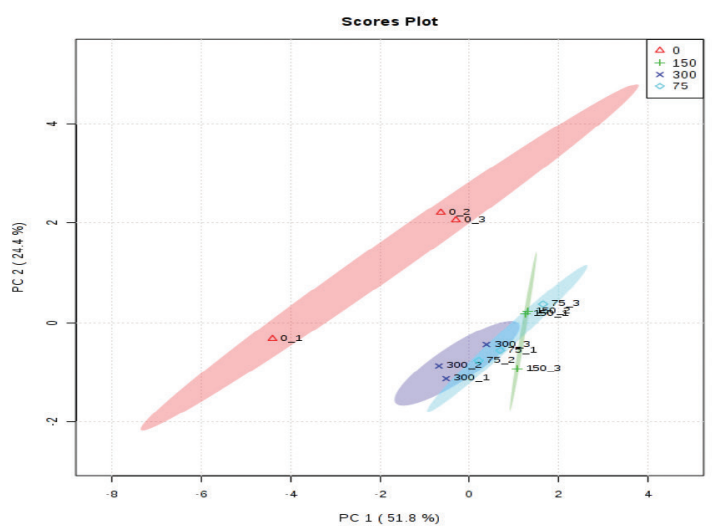

(B)

FIGURE 1. Projection of both principal components (PC) for PC1 and PC2 for season 1 (A) and season 2 (B). Homogeneous groups are in the same ellipse

PC2 $29.00 \%$ ) which gave an overview for season one (Figure 2). According to Liu et al. (2013), the rotational coefficient of variamax $>0.75$ has a strong correlation and is considered as a significant coefficient factor. This study observed that $B$. monnieri $(0.86)$ and $F$. miliaceae (0.93) have the highest value for PC1. Both species have positive correlation and they dominated in plots treated with 75 and $150 \mathrm{~g}$ ai/ha herbicide for season one. This can be defined again based on the relatively high density of this weed population when treated at rates of 75 and $150 \mathrm{~g}$ ai/ha (Table 1). Conversely, C. iria species also has a high rotation value but negatively associated with PC1. The position of the weedy rice and $C$. iria on the left side of PC1 (Figure 2) shows that both species are less dense for 75 and $150 \mathrm{~g}$ ai/ha spray plots. A. sessilis, $P$. distichum and weedy rice varieties recorded $0.54,0.77$ and 0.74 , respectively, for the rotation of variamax. All three species have the positive correlation positioned in the $0 \mathrm{~g}$ ai/ha spray plot for the season one. The presence of weedy rice found only in the control plots showed that the herbicides used were able to control the weedy rice as confirmed by other researchers (Azmi et al. 2012; Duong et al. 2007; Sudianto et al. 2013). However, the application of this herbicide does not necessarily control the growth of other weeds such as $B$. monnieri, F. miliacea and A. sessilis (Andres et al. 2013; Schaedler et al. 2013; Singh et al. 2017).

For season two, the PCA shows that both major PCs contributed $76.20 \%$ of the total variance (PC1 $45.40 \%$; PC2 30.80\%) which gave an overview for the second season (Figure 3). The value of each PCs for the season two is showed in Table 5. B. monnieri, A. sessilis and $L$. chinensis have the highest value of variamax rotation for PC 1 of $0.91,0.95$ and 0.59 , respectively. These three values have a positive correlation value to PC 1 and these species are dominated by 75 and $150 \mathrm{~g}$ ai/ha herbicides. For the season two, there was no high negative correlation value as shown in season one.

However, the position of the species Echinochloa glabrescens makes this species less dense for herbicide rates of 75 and $150 \mathrm{~g}$ ai/ha (Figure 3). Based on Table 5, there are only two species that have a positive relationship 


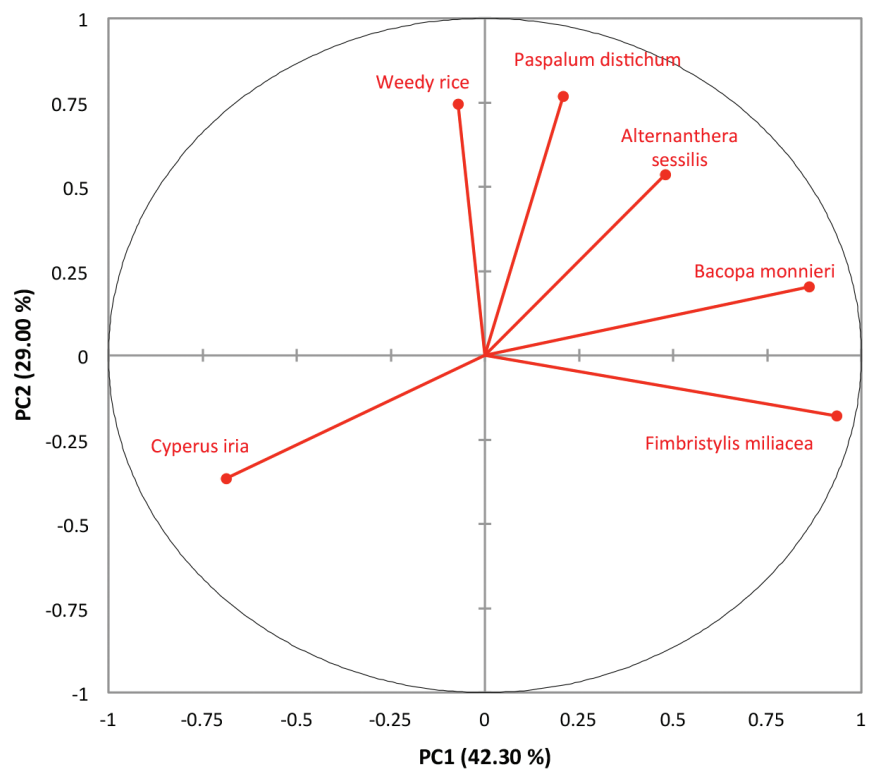

FIGURE 2. Variables (PC1 and PC2 axes: 71.30\%) after the varimax rotation for season one

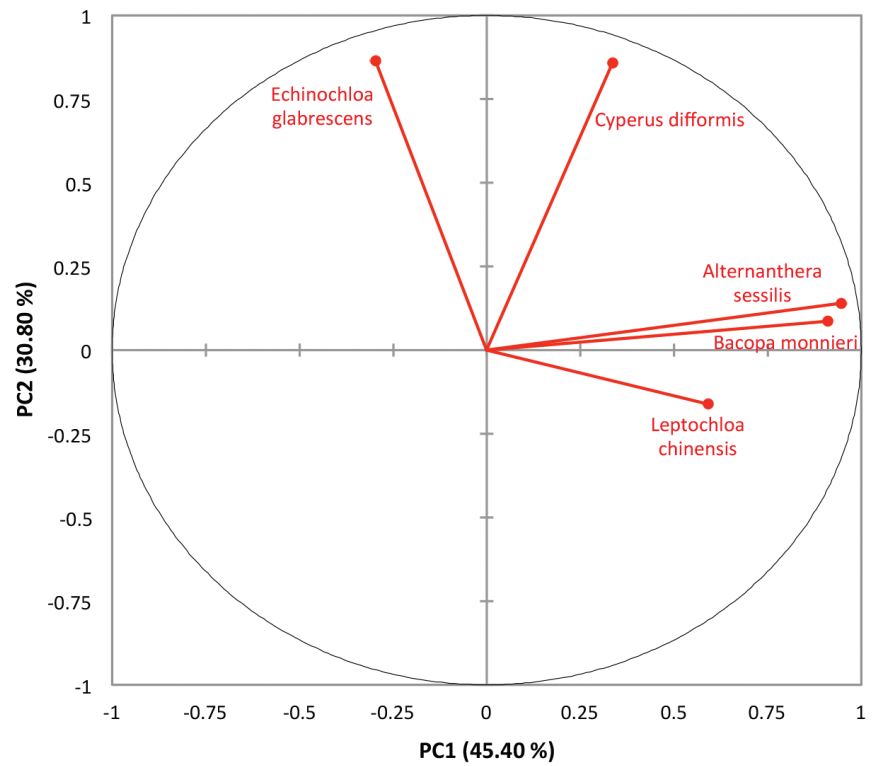

FIGURE 3. Variables (PC1 and PC2 axes: 76.20\%) after the varimax rotation for season two

with PC2. C. difformis and E. glabrescens recorded high rotational values of 0.86 and 0.87 , respectively. These species obtained the positive correlation conquered in control and $300 \mathrm{~g}$ ai/ha plots for season two. In the season two, weedy rice is hardly found in the control plot.

The presence of different species in the season one and two shows that the environmental factors greatly influence the weed population in rice ecosystems. Table 6 shows the average rainfall and temperature for season one and two. The average temperature and rainfall in each season are $27.7^{\circ} \mathrm{C}$ and $7.53 \mathrm{~mm}$, respectively, while the second season is $28.9^{\circ} \mathrm{C}$ and $4.7 \mathrm{~mm}$. Low rainfall in March 2016 might have resulted most of rice fields become dry and only the adjacent part of paddy field located near to the water source receive ample water for irrigation.

Under submerged conditions, B. monnieri and $A$. sessilis are mostly found whereas the rice fields are covered by $L$. chinensis and $C$. difformis at relatively dry areas. Based on the study conducted by Juraimi et al. (2011), wider leaf weeds are easier to survive in any state of the water capacity in soil than tapered weeds and sedges during harvesting days. The lack of water sources also causes rice plants grow slower and this condition could promote the growth of weeds (Ahmadikhah \& Marufinia 2016; Hussain et al. 2008). 
TABLE 6. Average temperature and rainfall for the season one (September - December 2015) and season two (February - May 2017)

\begin{tabular}{|c|c|c|c|c|c|}
\hline \multicolumn{3}{|c|}{ Season 1} & \multicolumn{3}{|c|}{ Season 2} \\
\hline Month & Temperature, ${ }^{\circ} \mathrm{C}$ & Rainfall, mm & Month & Temperature ${ }^{\circ} \mathrm{C}$ & Rainfall, mm \\
\hline September & 27.9 & 3.9 & February & 27.9 & 7.1 \\
\hline October & 27.8 & 8.1 & March & 29.3 & 0.2 \\
\hline November & 27.5 & 8.3 & April & 29.6 & 4.0 \\
\hline December & 27.6 & 9.8 & May & 28.8 & 7.5 \\
\hline Average & 27.7 & 7.53 & Average & 28.9 & 4.7 \\
\hline
\end{tabular}

\section{CONCLUSION}

Application of OnDuty ${ }^{\mathrm{TM}}$ (imazapic and imazapyr) in two planting seasons could exhibit slight differences in weed species compostion. A. sessilis and B. monnieri are the most abundant weeds found in both seasons. However, $F$. miliacea and weedy rice were found in the season one but not in the season two. Higher rate of herbicide up to $300 \mathrm{~g}$ ai/ha did not affect the relative density of weeds and weedy rice can be controlled at low concentrations, $75 \mathrm{~g}$ ai/ha which is half of the recommended rate. The average yield of rice per hectare decreased during the season two due to the shortage of rainfall. The PCA analysis supported the connection of herbicide rate to the relative density of weeds for both rice cultivation seasons which indicated that $B$. monnieri had a positive correlation and dominated 75 and $150 \mathrm{~g}$ ai/ha spray plots for both seasons. The Clearfield ${ }^{\circledR}$ production system offers control of many weeds missed by other herbicides and adds an effective weed-control tool to rice. The system is particularly effective for parasitic weed control and it can prevent crop injury caused by herbicide carryover. However, farmers have complained that some weed species still cannot be controlled effectively by OnDuty ${ }^{\mathrm{TM}}$ herbicide. Thus, further study should be carried out to determine the evolution of herbicide resistant-weeds to acetolactate synthase (ALS) inhibitors in rice fields.

\section{ACKNOWLEDGEMENTS}

Authors are grateful to Universiti Kebangsaan Malaysia for financial support through university research grant, GUP-2014-087 and BASF Malaysia grant (ST-2015-011). We are most grateful and would like to thank the reviewers for their valuable suggestions, which led to a substantial improvement of the article.

\section{REFERENCES}

Ahmadikhah, A. \& Marufinia, A. 2016. Effect of reduced plant height on drought tolerance in rice. 3 Biotech. 6(2): 221.

Ahmed, S. \& Chauhan, B.S. 2014. Performance of different herbicides in dry-seeded rice in Bangladesh. The Scientific World Journal 2014(3): 729418.

Altieri, M.A. \& Liebman, M. 1988. Weed Management in Agroecosystems: Ecological Approaches. Boca Raton: CRC Press.

Andres, A., Theisen, G., Concenço, G. \& Galon, L. 2013. Weed resistance to herbicides in rice fields in Southern Brazil. In
Herbicides-Current Research and Case Studies in Use, edited by Price, A.J. \& Kelton, J.A. Rijeka: InTech. pp. 3-25.

Azmi, M. 2002. Weed succession as affected by repeated applications of the same herbicide in direct-seeded rice field. Journal of Tropical Agriculture and Food Science 30: 151-162.

Azmi, M. \& Baki, B. 2007. Weed flora landscapes of the muda rice granary in the new millennium: A descriptive analysis. Journal of Tropical Agriculture and Food Science 35: 319331.

Azmi, M., Azlan, S., Yim, K.M., George, T.V. \& Chew S.E. 2012. Control of weedy rice in direct-seeded rice using the Clearfield $\AA^{\circledR}$ Production System in Malaysia. Pakistan Journal of Weed Science Research 18: 49-53.

Bajrai, F.S.M., Sahid, I. \& Jansar, K.M. 2017. Optimization method for simultaneous extraction and detection of imazapic and imazapyr herbicides in soil and water using HPLC-UV with verification of LC-MS. Sains Malaysiana 46(12): 2339-2348.

Bajrai, F.S.M., Ismail, B.S. \& Mardiana-Jansar, K. 2015. Rapid diagnosis of imazapic \& imazapyr resistance by using bioassays in Clearfield ${ }^{\circledR}$ Production System, Malaysia. AIP Conference Proceedings. p. 020008.

Basuchaudhuri, P. 2014. Cold Tolerance in Rice Cultivation. Boca Raton: CRC Press.

Begum, M., Juraimi, A.S., Amartalingum, R. \& Syed, S.R. 2009. Effect of Fimbristylis miliacea competition with MR220 rice in relation to different nitrogen levels and weed density. International Journal of Agriculture and Biology 11(2): 183-187.

Bhager, R., Bhuiyan, S., Moody, K. \& Estorninos, L. 1999. Effect of water, tillage and herbicide on ecology of weed communities in intensive wet-seeded rice system. Crop Protection 18(5): 293-303.

Bouterfas, K., Mehdadi, Z., Benmansour, D., Khaled, M.B., Bouterfas, M. \& Latreche, A. 2014. Optimization of extraction conditions of some phenolic compounds from White Horehound (Marrubium vulgare L.) leaves. International Journal of Organic Chemistry 4(4): 17.

Brower, J.E. \& Zar, J.H. 1984. Field and Laboratory Methods for General Ecology. 2nd ed. Iowa: Wm. C. Brown Co. Publishers.

Cattell, R. 2012. The Scientific Use of Factor Analysis in Behavioral and Life Sciences. New York: Springer.

Chauhan, B.S., Abeysekera, A.S., Wickramarathe, M.S., Kulatunga, S.D. \& Wickrama, U.B. 2014. Effect of rice establishment methods on weedy rice (Oryza sativa $\mathrm{L}$.) infestation and grain yield of cultivated rice $(O$. sativa $\mathrm{L}$.) in Sri Lanka. Crop Protection 55: 42-49.

Cousens, R. 1985. A simple model relating yield loss to weed density. Annals of Applied Biology 107(2): 239-252. 
De Datta, S.K. 1981. Principles and Practices of Rice Production. Singapore: John Wiley \& Sons, Inc.

De Vida, F.B.P., Laca, E.A., Mackill, D.J., Fernández, G.M. \& Fischer,A.J. 2006. Relating rice traits to weed competitiveness and yield: A path analysis. Weed Science 54(6): 1122-1131.

Duong, V.C., Tran, C.T., Huynh, H.B. \& Nguyen, T.N. 2007. Study on weed and weedy rice control by imidazolinone herbicides in Clearfield® paddy grown by IMI-tolerant indica rice variety. Omonrice 15: 63-67.

Faruk, M., Rahman, M. \& Hasan, M. 2009. Effect of seedling age and number of seedling per hill on the yield and yield contributing characters of Brri Dhan 33. International Journal of Sustainable Crop Production 4(1): 58-61.

Mohd Fuad, M.J., Junaidi, A.B., Habibah, A., Hamzah, J., Turiman, M.E., Lyndon, N., Selvadurai, A.C.Er.S. \& Azima, A.M. 2012. The impact of pesticides on paddy farmers and ecosystem. Advances in Natural and Applied Sciences 6(1): 65-70.

Hakim, M., Juraimi, A., Ismail, M.R., Hanafi, M. \& Selamat, A. 2013. A survey on weed diversity in coastal rice fields of Sebarang Perak in Peninsular Malaysia. Journal of Animal and Plant Sciences 23: 534-542.

Ho, N. \& Zuki, I.M. 1988. Weed population changes from transplanted to direct seed rice in the Muda Area. Proceedings of the National Seminar and Workshop on Rice Field Weed Management. pp. 55-67.

Holst, N., Rasmussen, I. \& Bastiaans, L. 2007. Field weed population dynamics: A review of model approaches and applications. Weed Research 47(1): 1-14.

Hossain, A.Z.\& Rahman, M.A. 2013. Effect of herbicides on the growth, yield components and yield of Br11 Paddy. Journal of the Asiatic Society of Bangladesh, Science 39(1): 21-26.

Hussain, S., Ramzan, M., Akhter, M. \& Aslam, M. 2008. Weed management in direct seeded rice. Journal of Animal and Plant Science 18(2-3): 86-88.

Jahan, M.S. 2004. Rice production under different water inputs. $\mathrm{PhD}$ Thesis. Universiti Putra Malaysia (Unpublished).

Juraimi, A.S., Muhammad Saiful, A., Uddin, M.K., Anuar, A. \& Azmi, M. 2011. Diversity of weed communities under different water regimes in Bertam irrigated direct seeded rice field. Australian Journal of Crop Science 5(5): 595-604.

Juraimi, A.S., Saiful, M., Begum, M., Anuar, A.R. \& Azmi, M. 2009. Influence of flooding intensity and duration on rice growth and yield. Pertanika Journal of Tropical Agricultural Science 32(2): 195-208.

Kim, D., Brain, P., Marshall, E. \& Caseley, J. 2002. Modelling herbicide dose and weed density effects on crop: Weed competition. Weed Research 42(1): 1-13.

Kim, J.O. \& Mueller, C.W. 1978. Factor Analysis Statistical Methods and Practical Issues. Beverly Hills: SAGE Publications.

Kim, S.C. \& Keith, M. 1983. Comparison of some methodologies for vegetation analysis in transplanted rice. Korean Journal of Crop Science 28(3): 310-318.

Krzyśko-Łupicka, T., Kręcidło, Ł. \& Kręcidło, M. 2016. The comparison of cellulolytic activity of the modified soil treated with Roundup ${ }^{\circledR}$. Chemistry-Didactics-Ecology-Metrology 21(1-2): 133-139.

Liu, J.X., Wang, Y.T., Zheng, C.H., Sha, W., Mi, J.X. \& Xu, Y. 2013. Robust PCA based method for discovering differentially expressed genes. BMC Bioinformatics 14(8): 1-10.

Mishra, S., Tripathi, A., Tripathi, D.K. \& Chauhan, D.K. 2015. Plant-Environment Interaction: Responses and Approaches to Mitigate Stress. New Jersey: John Wiley \& Sons.
Moody, K. \& Drost, D. 1983. The role of cropping systems on weeds in rice. Proceedings of the Conference on Weed Control in Rice. pp. 73-86.

Moody, K. 1989. Weeds Reported in Rice in South and Southeast Asia. Los Banos: International Rice Research Institute.

Moon, B., Kim, J., Cho, S., Park, J., Song, J. \& Kim, D. 2014 Modelling the effects of herbicide dose and weed density on rice-weed competition. Weed Research 54(5): 484-491.

Moon, B.C., Cho, S.H., Do Kwon, O., Lee, S.G. \& Lee, B.W. 2010. Modelling rice competition with Echinochloa crus-galli and Eleocharis kuroguwai in transplanted rice cultivation. Journal of Crop Science and Biotechnology 13(2): 121-126.

Naidu, V.S.G.R. 2012. Hand Book on Weed Identification. India: Directorate of Weed Science Research.

Noda, K. 1977. Integrated weed control in rice. In Intergrated Control of Weeds, edited by Fryer, J.D. \& Matsunaka, S. Tokyo: Univ. of Tokyo Press. pp. 17-46.

Oveisi, M., Mashhadi, H.R., Yousefi, A., Alizade, H., Baghestani, M. \& Gonzalez-Andujar, J. 2013. Predicting maize yield in a multiple species competition with Xanthium strumarium and Amaranthus retroflexus: Comparing of approaches to modeling herbicide performance. Crop Protection 45: 15-21.

Pane, H., Noor, E.S., Dizon, M. \& Mortimer, A.M. 2000. Weed communities of gogorancah rice and reflections on management. In Characterizing and Understanding Rainfed Rice Environments, edited by Tuong, T.P., Kam, S.P., Bouman, B., Pandey, S., Wade, L. \& Hardy, B. Manila: International Rice Research Institute. pp. 269-287.

Rao, A., Johnson, D., Sivaprasad, B., Ladha, J. \& Mortimer, A. 2007. Weed management in direct-seeded rice. Advances in Agronomy 93: 153-255.

Saharan, H.A. 1977. Rice weed control in Malaysia. MARDI Report No. 66, Serdang: MARDI. Sastroutomo, S.S. \& Pandegirot, E.T. 1988. Survai ekologis gulma di perkebunan teh Ciliwung. Prosiding Konferensi HIGI IX.

Schaedler, C., Noldin, J., Eberhardt, D., Agostinetto, D. \& Burgos, N. 2013. Globe Fringerush (Fimbristylis miliacea) cross resistance to als-inhibitor herbicides under field conditions in irrigated rice in the South of Brazil. Planta Daninha 31(4): 893-902

Seng, C.T., Kent, L.W. \& Ismail, B.S. 2018. Potential of oil palm frond residues in combination with S-Metolachtor for the inhibition of selected herbicide-resistant biotypes of Goosegrass emergence and seedling growth. Sains Malaysiana 47(4): 671-682.

Singh, A., Nandal, D. \& Punia, S. 2017. Bio-efficacy of sequential application of herbicides on weeds and yield in direct seeded rice (Oryza sativa). International Journal of Current Microbiology and Applied Sciences 6(4): 900-905.

Skinner, G.M. \& Taylor, M.C. 2002. Benzofenap: A new herbicide for weed control in water-seeded rice. Proceedings of Second Temperate Rice Conference. pp. 567-577.

Smith, C.W. \& Dilday, R.H. 2003. Rice: Origin, History, Technology, and Production. Toronto: John Wiley \& Sons, Inc.

Streibig, J.C. 1980. Models for curve-fitting herbicide doseresponse data. Acta Agriculturae Scandinavia 30: 59-64.

Sudianto, E., Beng-Kah, S., Ting-Xiang, N., Saldain, N.E., Scott, R.C. \& Burgos, N.R. 2013. Clearfield ${ }^{\circledR}$ Rice: Its development, success, and key challenges on a global perspective. Crop Protection 49: 40-51. 
Sundaru, M. 1979. A review on the use of 2,4-D and MCPA in farmer's rice fields. Proceedings of Fifth Indonesian Weed Conference 1979. pp. 1-434.

Tanaka, I., Nojima, K. \& Uemura, Y. 1963. Influence of drainage on the growth of rice plant in rice field: ii) relation between irrigation methods and the growth and yield of rice at various levels of nitrogen fertilization and sowing density. Japanese Journal of Crop Science 32(1): 89-93.

Watanabe, H. 1997. Emergence of major weeds and their population change in wet-seeded rice fields of the Muda Area, Peninsular Malaysia. Proceedings of the 16th Asian-Pacific Weed Science Society Conference. pp. 246-250.

Weiner, J., Griepentrog, H.W. \& Kristensen, L. 2001 . Suppression of weeds by spring wheat Triticum aestivum increases with crop density and spatial uniformity. Journal of Applied Ecology 38(4): 784-790.

Xia, J., Psychogios, N., Young, N. \& Wishart, D.S. 2009. Metaboanalyst: A web server for metabolomic data analysis and interpretation. Nucleic Acids Research 37(2): W652-W660.
Centre for Earth Sciences and Environment

Faculty of Science and Technology

Universiti Kebangsaan Malaysia

43600 UKM, Bangi, Selangor Darul Ehsan

Malaysia

*Corresponding author; email: mardiana@ukm.edu.my

Received: 15 April 2019

Accepted: 15 August 2019 